\title{
Review on the Current Status of Poverty and Its Determinants in Ethiopia
}

\author{
Zinabu Ambisa* Ahimed Umer Tilahun Kenea \\ College of Agriculture and Forestry, Mettu University, P.O.Box318, Bedele, Ethiopia
}

\begin{abstract}
The study was mainly focused on assessing current poverty status and its determinants in Ethiopia. Specifically aims to review the level of poverty status, causes of poverty and determinants of poverty in Ethiopia. However, its total population is more than 100 million; agriculture is the foundation of its economic growth. Poverty is still a big obstacle to overcome in Ethiopia. Poverty in Ethiopia is caused population pressure, illiteracies, and natural factors like drought, famine etc. Disease, shortage of land, poor use of technology, weak basic services, political instability, inflation, high unemployment rate and etc. Based on generalized results of we reviewed documents the major determinants of poverty were age of household heads, family size per adult equivalent, access to credit service, dependency ratio, and access to health service. Hence, promoting equitable economic growth, family planning, increasing land productivity, increasing credit service, increasing health service, and promoting research extension farmer linkage are indispensable policy interventions to better reduce rural poverty.
\end{abstract}

Key words: Poverty, Determinants, Ethiopia

DOI: $10.7176 / \mathrm{JPID} / 50-04$

Publication date:June $30^{\text {th }} 2019$

\section{Introduction}

\subsection{Back ground and justification}

Ethiopia is one of the world's poorest countries by any standard. According to a recent World Development Report, the country has the lowest GNP per head in the world, and its purchasing power parity adjusted GNP is ranked 200th out of 206 countries (World Bank, 2000). Human development indicators of the United Nations Development Program (UNDP) also attest to the seriousness and extent of poverty in the country. For instance, the Human Development Index (HDI) of Ethiopia is the sixth lowest out of 175 countries in the world. Similarly, the Human Poverty Index (HPI) ranks Ethiopia 91st out of 94 developing countries (UNDP, 2003).

The poverty experienced by many Ethiopians is reflected in a range of wellbeing measures of the population. For example, the life expectancy at birth in the country is approximately 46 years, which is substantially lower than the average 77 and 67 years recorded for countries with high and medium human development indices respectively. Moreover, three quarters of the population do not have access to an adequate water source, a figure that is amongst the highest for countries experiencing a low measure of human development. The percentage of population with access to suitable sanitation, which stands at 12 per cent, is significantly lower than the 53 per cent average for the sub-Saharan Africa (UNDP 2003, pp. 237-257). On the other hand, the adult illiteracy rate at around 60 percent is significantly higher than the average for sub-Saharan Africa and other developing countries.

The socio-economic predicament in Ethiopia is deep rooted and a result of the interplay of many factors. Mismanagement of the economy on the part of successive governments and three decades of civil war have greatly contributed to the present poor state of the country's economy.

Nonetheless, there have been some encouraging developments since 1991 with the end of the civil war and a change of government. The new government launched a sweeping program of economic reforms to revive the economy and four Policy Framework Papers aimed at macroeconomic stabilization and poverty reduction have been implemented since 1992/93. This program of reforms was developed in conjunction with the International Monetary Fund and the World Bank and saw devaluation of the Ethiopian currency (Birr), commodity market liberalization and a reduction in urban subsidies as part of the Structural Adjustment Program (SAP). Further, a ten-year development strategy, called Agricultural Development-Led Industrialization (ADLI), was also laid out. As stated in the Poverty Reduction Strategy Paper (PRSP), ADLI envisages fostering economic growth with the aim of reducing poverty (Federal Democratic Republic of Ethiopia, 2000). Indeed, a recurring theme in these programs is the reduction of poverty amongst the population.

The pre occupation with poverty reduction is warranted since a sizable proportion of Ethiopia's population lives in extreme poverty. The Human Development Report, for instance, reports that 81.3 percent of the population survives on less than \$US1 a day (UNDP, 2003). Although this may tend to overstate the incidence of poverty since the $\$ 1$ poverty threshold used by the UNDP is much larger than the amount of expenditure needed to purchase the absolute minimum basket in Ethiopia, it is still the case that poverty is a widespread problem in Ethiopia (Dercon etal, 1999). A range of studies report that between 35 to 50 per cent of the population is poor. Previous analyses of poverty in Ethiopia have generally focused on rural rather than urban areas. This is 
understandable in light of the fact that around 85 per cent of the population lives in rural areas. Unfavorable weather fluctuations may take a heavy toll on the lives of rural farmers and bring them to the brink of starvation. It is the plight of urban Ethiopians; however, that is the focus of the analysis in this paper. Although urban Ethiopians generally enjoy a higher standard of living when compared to their rural counterparts, poverty remains a problem in urban areas (Tadesse, 1999). Indeed, the worsening of the poverty situation in urban areas in part reflects policy choices made under the SAP. For instance, privatization of state-owned enterprises and stream lining of the civil service have led to the retrenchment of some workers in urban areas.

Further, the lifting of subsidies on basic goods and services, public expenditure cuts, tax reform measures and monetary contraction have all contributed to the persistence of poverty amongst urban Ethiopians (Tadesse, 1999).

The Ethiopian Ministry of Finance and Economic Development (MoFED) assessed the 1999/2000 HICE and Welfare Monitoring Survey results and concluded that the incidence of poverty is higher in rural than in urban areas with poverty head count ratio of 45.4 and 36.9\%, respectively (MOFED, 2002). However, as compared to the $1995 / 96$ level, poverty incidence increased by $11.4 \%$ in urban areas and declined by $4.42 \%$ in rural areas in 1999/2000 even though the overall poverty incidence decreased by $2.86 \%$ during the same period.

\subsection{Objectives of the review}

This review is conducted to address the following objectives:

1. To review the level of poverty status in Ethiopia

2. To review the causes of poverty in Ethiopia.

3. To review the determinants of poverty in Ethiopia.

This review paper is organized as follows. In the first section background and justification as well as objectives of the review have been discussed. In the second section conceptual issues associated with the measurement of poverty and empirical literature review are briefly considered. The final section will set out some concluding remarks and policy implications of the review.

\section{Literature Review \\ 2.1 Concept of poverty}

Poverty is one of the core issues and the most widespread social problems in the world. It has no geographical boundary. It is found in all directions and corners. Despite world exceptional advances in science, technology and wealth creation, poverty in all its manifestations remains deep and persistent. Poverty is multifaceted and has no single generally accepted definition (Ibrahim etal, 2008). Indeed, it is multidimensional. As a result literatures on the concept of poverty show various interpretations in economic, social, political, institutional, environmental and cultural contexts.

As of World Bank (2005), poverty is defined as a deprivation in well-being, and encompasses many dimensions. It, besides the inability to acquire the basic goods and services, consists of low levels of health and education, poor access to clean water and sanitation, inadequate physical security, voicelessness, and insufficient capacity and opportunity to better one's life.

In the same way, Bradshaw (2005) expressed poverty, generally, as a lack of necessities. Basic food, shelter, medical care, and safety are generally considered essential based on shared values of human dignity. Nevertheless, what is a necessity to one person is not equally a necessity to others.

Other writers, like Lehning (2006), Frerer and $\mathrm{Vu}$ (2006) and Wolf (2006) also defined and expressed poverty from their own viewpoint and field of study. However, all the approaches and definitions of poverty reveal as a state of human wellbeing deprivation.

Poverty is a threat to the world, especially developing countries. The governments, national and international development institutions have tried to understand the nature of poverty and mechanisms of reducing it. Poverty alleviation is a key policy debate in recent development literature. Many researchers of development economics have argued that the fight against poverty is a necessary condition for sustainable economic growth.

As stated in Oyekale (2011) poverty reduction is the issue that reconsidered as one of the brightest indicators of human progress. Poverty is blessed with a rich vocabulary, in all cultures and throughout history. Rowntree's study, published in 1901 was the first to develop a poverty standard for individual families, based on estimates of nutritional and other requirements. In the $1960 \mathrm{~s}$, the main focus was on the level of income, reflected in macro-economic indicators like Gross National Product per head. In the 1970s, poverty became prominent, notably as a result of McNamara's celebrated speech to the World Bank Board of Governors in Nairobi in 1973. Other factors that played a big role include the emphasis on relative deprivation, inspired by work in the UK by Runciman and Townsend. Townsend had the opinion that poverty was not just a failure to meet minimum nutrition or subsistence levels, but rather a failure to keep up with the standards prevalent in a 
given society. Thus, following ILO's pioneering work in the mid-1970s; poverty came to be defined not just as lack of income, but also as lack of access to health, education and other services.

The concept of basic needs inspired policies like integrated rural development. New layers of complexity were added in the 1980s. The principal innovations were: (a) the incorporation of non-monetary aspects, particularly as a result of Robert Chambers' work on powerlessness and isolation. (b) A new interest in vulnerability, and its counterpart, security, associated with better understanding of seasonality and of the impact of shocks, notably drought. This pointed to the importance of assets as buffers, and also to social relations (the moral economy, social capital). It led to new work on coping strategies. (c) A broadening of the concept of poverty to a wider construct, livelihood. (d) Theoretical work by Amartya Sen. (1981), who had earlier contributed the notion of food entitlement, or access, emphasized that income was only valuable in so far as it increased the capabilities of individuals and there by permitted functioning's in society. (e) A rapid increase in the study of gender. Policies followed to empower women and find ways to underpin autonomy, or agency. In 1990s UNDP developed the idea of human development: 'the denial of opportunities and choices to lead a long, healthy, creative life and to enjoy a decent standard of living, freedom, dignity and self-esteem'.

\subsection{Theoretical Approaches to Poverty Analysis}

The main objective of all approaches of poverty analysis is primarily to determine who are the poor households, individuals, or groups of individuals? There are two main approaches for estimating welfare for the purposes of analyzing poverty: Those that are based on an indicator of welfare, hence the name of the welfare approach which refers to the microeconomic concept of utility. The second approach is known as the non-welfare approach which is basically regarded as being more social in character than the welfare approach (Boccanfuso, 2004).

The welfare approach refers to the numerous microeconomic precepts that postulate that economic actors are rational and that they behave in ways to maximize their benefit (welfare). Since economic welfare is not observable, the welfares school has fallen back on real income and consumption expenditures as indicators of economic welfare. This is the approach advocated by the World Bank, the IMF, and the main development partners (Boccanfuso, 2004).

The non-welfare approach is more sociological in nature. In contrast to the previous approach, this has to date been a multidimensional approach. There are two schools under this approach: The first is the basic needs school and the second is the capabilities. The basic needs approach appeared in its operational guise in the 1970s in response to the policies for the fight against poverty proposed by the welfares, and particularly to the policies of growth trumpeted as a tool for reducing poverty. It views poverty as a problem of unacceptable social inequality (Kanbur, 2002). Sen.'s (1981) school of capabilities approach was also developed in opposition to the welfare approach. The aim in this approach is for an individual or household to have the capacity to function well in society and not solely on the basis of its own functions.

In this context, this agent cannot be considered poor, even if she/he decides not to achieve certain functions, provided that he/she has the possibility to select them from the total range of functions.

\subsubsection{The meaning of poverty}

Poverty - just like its conceptual and social structural opposite pole, wealth - has many dimensions and manifestations. It always means a reduced (or complete lack of) access to material, economic, social, political or cultural resources needed to satisfy basic needs. As a multidimensional phenomenon, poverty is defined and measured in a multitude ways. This section describes the various meanings of poverty.

\section{$>$ Absolute and relative poverty:}

Poverty can be viewed in absolute and relative terms. Absolute poverty refers to subsistence below minimum, socially acceptable living conditions, usually established based on nutritional requirements and other essential goods (e.g. per capita income under a certain arbitrarily fixed poverty line in USD per unit of time, a daily intake of less than 2,150 calories/person/day, or Human Development Index). Relative poverty compares the lowest segments of a population with upper segments, usually measured in income quintiles or deciles may be quantified by concentrating on a small number of key indicators such as the share, in national wealth or income, possessed by $20 \%$ of the poorest inhabitants of a country.

\section{$>$ Objective and subjective perspectives:}

Poverty can be approached from objective or subjective perspectives. The objective perspective (sometimes referred to as the welfare approach) involves normative judgments as to what constitutes poverty and what is required to move people out of their impoverished state. The subjective approach places a premium on people's preferences, on how much they value goods and services (hence the emphasis on individual utility).

\section{$>$ Physiological and sociological deprivations:}

Poverty concepts can be divided into two types of deprivations - physiological and sociological. Regarding the former, the line of thinking is as follows: people are poor because they lack income, food, clothing and shelter. Both the income and basic needs concepts of poverty stem from physiological deprivations. The 
concepts of poverty emerging from the perspective of sociological deprivations are rooted in the underlying structural inequities and inherent disadvantages. They are based on observations that even when resources are flowing into sectors dominated by the poor, they may not be able to take full advantage because of social structural impediments.

\section{$>$ Poverty, equity, human rights and health: the links}

The links between the concepts of poverty, equity, and human rights in relation to health are many and profound. Both equity and human rights principles dictate striving for equal opportunity for health for groups of people who have historically suffered discrimination or social marginalization. Achieving equal opportunity for health entails not only buffering the health-damaging effects of poverty and marginalization: it requires reducing disparities between populations in the underlying conditions - such as education, living standards, and environmental exposures - necessary to be healthy. Thus, both human rights and equity perspectives require that health institutions deal with poverty and health not only by providing care to improve the health of the poor but also by helping to alter the conditions that create, exacerbate, and perpetuate poverty and marginalization.

\subsection{Level of Poverty Status in Ethiopia \\ 2.2.1 Measuring poverty}

The complexity of poverty has led to the development of various forms of measurements. Economists have given a great deal of attention to the functional form of a poverty measure, such as how the measure should respond to changes in distribution below the poverty line. A poverty line is defined as the monetary cost to a given person, at a given place and time, of a reference level of welfare. People who do not attain that level of welfare are deemed poor, and those who do are not (Ravalli on, 1998).

\section{* Consumption poverty measure:}

The Foster-Greer-Thorbecke Index (FGT, 1984) is a commonly used measure of poverty. It comprises the most desirable properties of a poverty index, such as decomposition and sub-group consistency. Consumption aggregates are calculated as the sum of food and non-food consumption expenditures. Food consumption is the sum of all food items consumed in the last week, including purchased (both raw cereals and prepared meals), from own stock, gifts and food-for-work in kind payments, scaled to a month by multiplying it by 4.28 (Dercon and Hoddinott, 2004). These consumption levels are calculated using prices obtained from local markets during the household surveys. Non-food consumption includes direct consumables such as matches, soap, linen and clothes. Expenditures on durables and non-durables and on schools, health, taxes and extraordinary contributions are excluded due to heterogeneity in responses in terms of these expenditures (see Dercon et al., 2009 for details). Total consumption expenditure is then calculated as the sum of food and non-food consumption, and is deflated by the 1994 prices (base year) in order to find real total consumption expenditure. Finally, the real consumption expenditure is divided by household size to obtain real consumption per capita expenditure. Following Dercon et al. (2009), a poverty line calculated using real consumption per capita expenditure is utilized to identify households as poor and non-poor.

\section{* Multidimensional poverty measure:}

An extensive debate on the concept of poverty measurement was raised after AmartyaSen's seminal work on poverty, famines, entitlements and deprivations (Sen, 1976; 1981; 1985). Sen (1985) defines poverty as lack of capability, where capability is defined as being able to live longer, to be well-nourished, healthy, and literate. This definition sets the basic grounds for the establishment of multidimensional poverty measures, which subsequently led to the development of various approaches and indices (such as asset-based approach and multidimensional poverty index) to capture poverty.

The basic idea of Multidimensional poverty index (MPI) is that the well-being of a household/individual depends not just on income or consumption, but also on several other dimensions or capabilities such as health, education, and standard of living (including assets and housing quality). The multi-dimensional poverty measure is more likely to underpin long-term poverty, whereby variables such as literacy or tangible assets are much more reasonable methods of poverty assessment (Hulme and Shepherd, 2003). In addition, consumption expenditure, as a flow variable, is more likely to capture mobility of households in to and out of poverty while the MPI poverty indices capture long-term well-being.

Bourguignon and Chakra arty (2003, pp.27) state that, “... a multidimensional approach to poverty defines poverty as a short fall from a threshold on each dimension of an individual's well-being." Following this definition, a plausible strategy to identify the poor is to compare each individual's achievements against the respective dimension-specific cutoffs and by looking at achievements across dimensions in order to arrive at complete specification of an identification method. Two commonly used identification criterion in MPI are the union and the intersection approaches. In the union approach, an individual or household is said to be multidimensionally poor if there is at least one dimension in which the person is deprived. The weakness of this approach is that when the number of dimensions is large, it will identify most of the population as being poor (Alkire and Foster, 2011). On the other hand, the intersection approach identifies a person as being poor only if 
the person is deprived in all dimensions. This approach, however, misses people who are experiencing extensive, but not universal deprivation.

An alternative and plausible approach uses an intermediate cutoff level that lies between these two extremes (Alkire and Foster, 2011). An individual is identified as deprived when the number of dimensions in which the person is deprived is at least above some minimum cutoff number of dimensions $(k)$. If the number of deprived dimensions falls below the cutoff $k$, then the person is not considered poor. This method of identification is referred to as the dual cutoff since it depends on both the within dimension cutoffs to determine whether a person is deprived in that dimension and across dimension cutoffs to identify the poor by 'counting' the dimensions in which a person is deprived.

\subsubsection{Poverty status in Ethiopia}

The proportion of people in poverty in Ethiopia has declined, reflecting an improvement in poverty situation of the country over the years (table 5). In 2010/2011, the headcount index was 29.6\%; a decline of about 10 percentage points compared to 2004/05. Even though rural poverty is, in general, higher than urban poverty; the rural-urban poverty gap is narrowing over time

Table 5: Trends of poverty in Ethiopia (1995/96-2010/11)

\begin{tabular}{lllll}
\hline \multirow{2}{*}{$1995 / 1996$} & & National & Rural & Urban \\
\cline { 3 - 4 } & Head count (P0) & 0.455 & 0.475 & 0.332 \\
& Depth of poverty(P1) & 0.129 & 0.134 & 0.099 \\
& Severity of poverty(P2) & 0.051 & 0.053 & 0.041 \\
\hline $1999 / 2000$ & Head count (P0) & 0.442 & 0.454 & 0.369 \\
& Depth of poverty(P1) & 0.119 & 0.122 & 0.101 \\
& Severity of poverty(P2) & 0.045 & 0.046 & 0.039 \\
\hline $2004 / 2005$ & Head count (P0) & 0.387 & 0.393 & 0.351 \\
& Depth of poverty(P1) & 0.083 & 0.085 & 0.077 \\
& Severity of poverty(P2) & 0.027 & 0.032 & 0.027 \\
\hline & Head count (P0) & 0.296 & 0.304 & 0.257 \\
& Depth of poverty(P1) & 0.078 & 0.080 & 0.069 \\
& Severity of poverty(P2) & 0.031 & 0.032 & 0.027 \\
\hline
\end{tabular}

Source: Mo FED (2012a).

Most of the reduction in poverty at the national level is attributed to reductions in rural poverty, which could be explained, in part, by favorable terms of trade for agriculture, increased delivery of public services, and improved infrastructure. The government allocated much of its resources to reducing structural bottlenecks in the economy by investing in basic economic welfare in rural areas.

However, it is important to consider the multidimensional nature of poverty and go beyond income and food provision. Poverty in Ethiopia includes many aspects, such as asset depletion, vulnerability, human capabilities, and lack of sustainable livelihoods. Even though improvements are being registered with respects to some indicators of welfare, a closer examination of the poverty situation in Ethiopia shows the prevalence of factors that contribute to the persistence of poverty.

These factors include low agricultural production, limited non-farm income, inadequate education, poor health, high population growth, and weak institutional structures.

According to data from CSA's 2004/05 Welfare Monitoring Survey (WMS), which provide outcome indicators on the non-income dimensions of poverty, education enrollment (1-6) has nearly doubled (74.2\%) compared to its level in 1995/96(37.4\%). Primary Gross enrollment as defined by the Ministry of Education (1-8) reached $67 \%$, which is in line with what is reported by the Ministry of Education $(68.4 \%)$ as an input to this APR. Note that what is reported here is based on sample and the Ministry's report is based on census from school reports. With regard to health, under 5immunization coverage for Measles and BCG increased from $39.1 \%$ and $35.1 \%$, respectively in 1996 to $56.8 \%$ and $52.5 \%$ in $2004 / 05(45.3 \%$ and $49.6 \%$ increase, respectively). With regard to access to clean water, overall access to clean water increased from about $19 \%$ in 1996 to $35.9 \%$ in 2004/05.This is also in line with what is reported by the Ministry of Water Resources(37.9\%),

\subsection{Causes of poverty}

In Ethiopia, agriculture is the backbone of Economy and agricultural production is the source of livelihood for millions of Ethiopians, especially for those in rural areas. According to Namara et al (2010), the persistent fluctuation in the amount and distribution of rainfall is considered as a major factor in rural poverty.

The causes of poverty can be attributed to different processes and multifaceted forces. This section tries to highlight some causes of the wide prevalence of poverty.

$>$ Warfare: The material and human destruction caused by warfare is a major development problem. For example, from 1990 to 1993, the period encompassing Desert Storm, per capita GDP in Iraq fell from $\$ 3500$ to $\$ 761$ (Dercon, 2001). The drop in average income, while a striking representation of the 
drop in the well-being of the average Iraqi citizen in the aftermath of the war, fails to capture the broader affects of damages to the infrastructure and social services, such as health care and access to clean water. However, there is no doubt that the persistent civil wars, like in the case of Angola, Mozambique and Liberia have contributed significantly in impoverishing those countries.

$>$ Agricultural cycles and natural disasters: Many families that rely on subsistence production for survival, the period immediately prior to harvest is a 'hungry period.' During these periods of scarcity, many families lack sufficient resources to meet their minimal nutritional needs. Moreover, natural disasters such as hurricanes, droughts, flooding and earthquakes have devastated communities throughout the world. Developing countries often suffer much more extensive and acute crises at the hands of natural disasters, because limited resources inhibit the construction of adequate housing, infrastructure, and mechanisms for responding to crises.

> Corruption and social inequality: Corruption often accompanies centralization of power, when leaders are not accountable to those they serve. Most directly, corruption inhabits development when leaders help themselves with money that would otherwise be used for development projects. There is another source of poverty throughout the world is social inequality that stems from cultural ideas about the relative worth of different genders, races, ethnic groups, and social classes. Ascribed inequality works by placing individuals in different social categories at birth, often based on religious, ethnic, or racial characteristics. For example in South African history, apartheid laws defined a binary caste system that assigned different rights (or lack thereof) and social spaces to Whites and Blacks, using skin color to automatically determine the opportunities available to individuals in each group.

$>$ Pervasive illiteracy and wide spread diseases: In least developed countries there is a high level of illiteracy. This is a very big problem in improving the livelihoods of people. The poor, who are also illiterate, have a limited chance of making use of improved production technologies and preventive health services. That is why diseases such as HI and Malaria have exacerbated the already precarious conditions of the poor. Diseases increase expenditure on health, at the same time reduces effective working time thus plummeting labor productivity and availability in the households. The association between diseases and poverty can be easily depicted using the case of HIV-AIDS.

$>$ Human capital $(\boldsymbol{H})$ : the skills, knowledge, ability to labor and good health important to the ability to pursue different livelihood strategies. Low human capital is both a cause and a consequence of poverty, and it interacts with other categories-for instance, the poor often cannot afford to send their children to school or clinics, thereby reinforcing low productivity and perpetuating dependence on 'low input, low output' agriculture.

$>$ Physical capital $(\boldsymbol{P})$ : the basic infrastructure (transport, shelter, water, energy and communications) and the production equipment and means that enable people to pursue livelihoods;

$>$ Social capital $(\boldsymbol{S})$ : the social resources (networks, membership of groups, relationships of trust, access to wider institutions of society) upon which people draw in pursuit of livelihoods;

$>$ Financial capital $(\boldsymbol{F})$ : the financial resources which are available to people (whether savings, supplies of credit or regular remittances or pensions) and which provide them with different livelihood options.

$>$ Natural capital $(N)$ : the natural resource stocks from which resource flows useful for livelihoods are derived (e.g. land, water, wildlife, biodiversity, environmental resources).

$>$ Finally, it is important to consider trends in the political capital of local communities-in other words, the extent to which they receive and support from central government and can exert influence over local political processes to access public resources. Poverty is a multi-faceted process. Poverty arises not only from low level of income but also from low and deteriorating stocks of and access to all types of assets and resources, at the community as well as the household level.

According to Asmamaw (2004) vulnerability to rural poverty are mainly caused by degraded natural resources, poor access to essential services, poor infrastructure, weak local institution, rain-fed agriculture system and low saving.

\subsection{Determinants of poverty in Ethiopia}

In order to identify the determinants of poverty, several studies have been conducted by various scholars and field experts in the different parts of the world. This discussion or review, however, focuses on the factors affecting poverty in rural areas of developing countries with special focus of Ethiopia.

Poverty has remained to be a worldwide problem and consequently it has been studied many times at both global and national level. Literatures on the concept of poverty show various interpretations in economic, social, political, institutional, environmental and cultural contexts. Poverty is a multidimensional and dynamic phenomenon. The definition of poverty is broad and subject to changes overtime. Traditionally, poverty is defined as lack of income or money, however, this approach is later extended to incorporate other important 
aspects of life.

Selim (2016) investigated the determinants of relative poverty in Turkey with a special emphasis on gender by using a panel Logit regression model. Their findings suggested that factors like being man, being married, higher level of education, higher level of age, improvement in health status, being employer and self-employed, having social security will reduce the probability of poverty in Turkey.

Chen and Wang (2014) analyzed the determinants of poverty in Taiwan, including family-level and regional-level factors. They analyzed data of 13,640 households from 23 cities and counties (regions) by hierarchical generalized linear models. Their results indicated that among the family-level factors studied, education, socioeconomic status, age, family type, dependency ratio, marital status, and number of earners are connected to poverty status. There were observed also significant relationships between poverty and structural characteristics, such as economic inequality, economic growth, structural transition, and labor market characteristics.

Khudri and Chowdhury (2013) identified the key determinants of poverty in Bangladesh using logistic regression model. Their findings suggest that a set of demographic variables such as division, type of place of residence, own land usable for agriculture, highest education level and employment status were the key determinants of poverty. Their results also revealed that ownership of agricultural land and having higher education would result in reduce the likelihood of being poor. Moreover, they found that the area of residence was statistically significant and a rural household had high probability of being poor than their urban counterparts.

Dartanto and Nurkholis (2013) used an ordered Logit model to examine the determinants of poverty dynamics in Indonesia by using the National Socio-Economic Survey balanced-panel data sets of 2005 and 2007. They found that $28 \%$ of poor households are classified as chronically poor while $7 \%$ of non-poor households are vulnerable to being transient poor. Their estimations also confirmed that the determinants of poverty dynamics in Indonesia are educational attainment, the number of household members, physical assets, employment status, health shocks, the microcredit program, access to electricity, and changes in employment sector and employment status. They also found that households in Java-Bali are more vulnerable to negative shocks than those outside Java-Bali.

Rupasingha and Gotez (2007) contributed to basic knowledge of the structural determinants of poverty in the US by analyzing an expanded set of determinants of poverty, namely factors related to economic, social, and political influence using spatial data analysis techniques. Social capital, ethnic and income inequality, local political competition, federal grants, foreign-born population, and spatial effects were found to be important determinants of poverty in US counties along with other conventional factors.

D' Ambrosio et al.(2011) examine the extent of poverty within five European countries, Belgium, France, Germany, Italy, and Spain. They use three different multidimensional approaches, with a variety of explanatory variables and Logit regression analysis to investigate the nature of poor households in the region. The study finds a U-shaped relationship between poverty and the size of the household as well as between poverty and the age of the individual. Unemployed individuals have a much higher probability of being poor while the probability of being poor seems to be lower among self-employed than among salaried workers. Moreover, married individuals, whatever their gender, have a lower probability of being poor than singles.

Andersson et al (2005) examined the determinants of income and poverty in Lao PDR. The result reveals that household size, dependency ratios, education, and access to agricultural inputs are among the main determinants of per capita consumption.

Alemayehu et al (2005) using household level data examined the determinants of poverty in Kenya. The study showed that poverty is strongly associated with the level of education, household size and engagement in agricultural activity in both rural and urban.

Ibrahim and Umar (2007) assessed the poverty status and its determinants in Nasarawa State, Nigeria. The results shows that the major determinants of poverty are household size, number of income sources of the household head, number of household members employed outside agriculture and the number of literate adult males and females in the household. In the same way, Adepoju(2012) conducted study in South West Nigeria to analyze poverty transitions in rural area. The results show an overlap between the causes of chronic and transient poverty.

Sabir et al (2006) presented the empirical findings on the poverty status and its causes among small farmers in the Pakistan. The result revealed that lower farm productivity, old age of the head, lower prices of the outputs, bigger household size, lack of infrastructure, and dependency ratio were the major determinants of poverty, whereas the education of the head was inversely related to poverty.

Hashmi et al (2008), in the same country, showed that the chance of being in poverty increased due to increase in household size, dependency ratio, while, education, value of livestock, remittances and farming decreased the likelihood of being a poor. The same history is explained in the work of Malik et al (2012).

Ibrahim and Umar (2008), in Nigeria, identified the major determinants of poverty include household size, 
number of income sources of the household head, number of household members employed outside agriculture and the number of literate adult males and females in the household.

In the same way, Apata et al (2010) examined the determinants of rural poverty in Nigeria. The results shows that access to micro-credit, education, participation in agricultural workshops/ seminars, livestock asset, and access to extension services significantly affect the probability of existing in poverty whereas female headed households' and distance to the market increases the probability of persistence in poverty.

Sekhampu (2013) showed that household size, age and the employment status of the household head significantly explain the variations in the likelihood of being poor in South Africa. The age and employment status of the household head reduces the probability of being poor, while household size is associated with an increased probability of being poor.

Bahta and Haile (2013) identified the determinants of poverty in Eritrea. The result of study shows that poverty status is negatively associated with education level, type of resident, size of land, number of meal, remittance, access of credit from relatives, credit institutions, opinion to credit, rain fed crop, irrigated crop, income from agriculture and income from -non agriculture. However, family number, number of children, children at school age and rent of land highly positively related to poverty.

In Ethiopian context, Maru (2004) conducted a study in Zeghe peninsula to identify the levels and determinants of rural poverty. The results reveal that land holding size, suitability of land for coffee production, participation in contractual farming activities, engagement in petty trading, beekeeping and fishing activities are negatively associated with the probability of households' falling into poverty. On the other hand, probability of being in poverty is positively related to high dependency ratio and participation in firewood selling activities.

Ayalneh et al (2005) stated that rural poverty is strongly linked to entitlement failures as explained by lack of crucial household assets such as land, human capital and oxen. The study suggests that improved targeting devices can be a useful instrument in reducing poverty, in particular to reach the poorest of the poor.

Swanepoel (2005), using Ethiopian Rural Household Survey (ERHS) from 1994-1997, studied poverty dynamics in rural Ethiopia. The study finds that transiently poor households have a higher dependency ratio, face more frequent crop failures, and have smaller areas of land available for cultivation. In contrast, chronically poor households own fewer assets and earn less from the sale of livestock.

In the same way, Bigsten and Shimeles (2008) analyzed poverty transition and persistence in Ethiopia using panel data of 1994-2004. The finding indicates that households in rural areas have a higher probability of ending poverty and lower probability of moving into than households in urban areas. The study found that household size, education of head of households, variation in rainfall and access to market are significant factors that will reduce transient poverty in rural areas.

Ahmed (2013) investigated the dynamics of poverty in rural Ethiopia during the period from 1994 to 2009. The result illustrates that the probability of being in poverty is a direct function of prior experience in poverty. Land size, oxen and other tropical livestock units have substantial impact in reducing the probability of being in poverty.

Tilman and Sindu (2013) also examined the dynamics and causes of consumption and multidimensional poverty in rural Ethiopia. The study noticed that poverty is mainly transient in Ethiopia. Household size, off farm employment, and short term shock such as drought significantly affect consumption poverty whereas simultaneous occurrence of many shock substantial determine multidimensional poverty.

Addisu and Rao (2014), using rural household survey, analyzed factors that make poverty to persist overtime with its consequences. The study identified age of household head; adult equivalent household size and religion of household head have significant positive effects on poverty status of the households. Nevertheless, poverty status is negatively associated with male headship, age square of household head, mean education of household, food aid, access to modern inputs, agricultural income per adult, social capital and ownership of durable goods.

Tesfahun (2005) revealed that poverty was found to rise with household size and access to microcredit (because of inappropriate use). However, rural poverty falls with higher level of education, size of cultivable land, number of oxen and other animals, and saving.

Bogale et al (2005) explored the determinants of rural poverty in Ethiopia. The study illustrates that rural poverty is strongly linked to entitlement failures understood as lack of household resource endowments to crucial assets such as land, human capital and oxen.

In the same way, Bogale (2011) also analyzed the extent and determinants of rural household poverty in the eastern highlands of Ethiopia. The study suggests that poverty is location specific, depends on access to irrigated land and access to non-farm income. The result also shows that household wellbeing is negatively affected by household size, and positively affected by age of household head. Probability of being in poverty is also strongly associated involvement in governance, social and production related networks.

Babu and Nega (2013) used cross-sectional household survey data to describe determinants of rural poverty in Gulomekeda wereda of Tigray National Regional, Ethiopia. The results of study reveal that total family size 
and dependency ratio have positive association with poverty of the household. While farm size, total livestock owned (TLU), value of asset, educational status of the household head, access to credit and access to off farm income have negative association with the households' poverty status.

Metalign (2005), in South west Shoa Zone of Ethiopia, identified that rural poverty decreases as the level of education, saving size of cultivable land and number of oxen and other animals owned increases. Household size and access to micro credit are positively linked to poverty. According to Ayalneh (2011), rural poverty in the eastern highlands of Ethiopia is determined by location, irrigation, non-farm income age, and household size among few. The result shows that poverty is location specific, depends on access to irrigated land and access to non-farm income. On the other hand, household's wellbeing is negatively affected by household size, and positively affected by age of household head.

As of the study by Tsegaye (2014) the main determinants of poverty in Gozamn district of East Gojjam, Ethiopia are education, livestock ownership, cultivated land holding, oxen holding, off-farm income, credit utilization and frequency of extension contact. They have a strong but a negative association with the poverty status of rural households. On the other hand, family size has a positive association with poverty status of rural households.

Poverty is so technical that it is very difficult to draw a single conclusion. What is more significant is that how poverty is defined and measured. It determines the types and directions of policies aimed at reducing poverty. However, identifying the causes of poverty can be complex exercise (Sekhampu, 2013). Hence, this study focused on identifying the determinants of poverty.

\subsubsection{Poverty determinant with respect to household demographics}

Household demographic composition like household size and age of the head are important covariates of poverty. The results regarding household headship, most empirical studies have discussed the phenomena of feminizing poverty which assumed that the prevalence of poverty is higher to female-headed households than male-headed ones. Additionally, different scholars support this assumption by providing various justifications. This could be due to the presence of discrimination against women in the labor market, or it might be because women tend tohave lower education than men do and therefore they are paid less salaries. Or else, they are in general deprived the opportunities of exercising when compared to men in many respects.

- The household head age and poverty. From different scholars there are different arguments some of them argue that poverty increases at old age. This is because productivity of the individual decreases and the individual has few savings to compensate for the decrease of productivity and income. This is, of course, more likely to be the case in developing countries where savings are low because of low income and at the old age being mostly dependent. The others contend that age is correlated with higher productivity and hence impacts welfare positively. A third view that could be worthy of note to see is that neither of the two approaches be correct. This is because the relationship between age and poverty might not be linear, as we would expect that incomes would be low at relatively young age, increases at middle age and then decreases again.

- Household family size and poverty: From different literature and report there is a linear relationship between poverty and household family size. As an example large households tend to associate with poverty (World Bank 1991 a, b), Lanjaw, and Ravallion (1994). The effect of household size on household well- being very much depends up on the degree of rivalry in consumption among household members. All consumption in the family is public so that every marginal increase in consumption benefits all household members.

- Marital status of the household head and poverty: Marital status of the household head is an important constituent of the demographic variables. But from different angles there is positive and vise verse between poverty and marital status of house household head analysis. Economic theory and most empirical literatures support the notion that the chance of falling into poverty increases as one is married. This is due to when people get married household size will increase as new children are born and expenditures increase which in turn leads to searching for mechanisms of fulfilling additional needs and necessities for the family. On the other hand as one is married the probability of falling into poverty decreases, as there is more labor forces in the household and unity.

- Educational level and Poverty: Most researchers and development specialists agree that investment on human capital has a very crucial role in tackling poverty and income inequality. Education is the major source of difference in earning power of individuals. At household level, education achievement of the head is considered to determine the poverty status of the household since the head is the most important bread winner, though not always the only. In addition, the head is the most important exponent of decision making in the household. The finding arrived by many researchers of poverty in urban Ethiopia shows inverse relationship between poverty status and education level. For instance, Kedir (2003) found that a negative and high association is found between the probability of being poor and educational level of the 
household head. Generally, the poor tend to have a head with low education achievements.

- Occupational groups and poverty: The type of economic engagement has also been important in determining the probability of a household falling under poverty in many urban poverty researches. For instance in Ethiopia, poverty is found to be more widespread among some occupational groups although it differs from town to town. A good example of this cited in the empirical literature part is Kedir (2003) finding which approves that poverty is related with unemployment and casual employment of the head. In addition, the duration of unemployment and the type of economic engagement before unemployment may determine the probability of a household with unemployed head being poor. If the duration of unemployment is a short time, it may not have strong impact on the household's probability of being poor. Similarly, if the previous economic engagement of the unemployed head was well paying, then he/she would have better opportunity of acquiring wealth. On the other hand pensioners are more vulnerable to poverty next to casual. This may be due to as the household head become pensioner his level if income decrease.

- Saving and poverty: Another way of looking at the life standard of the households is to assess their saving status. A question introduced to assess the status of saving among the households was "why not the family saves" if they were first identified as non-savers. Three alternatives were suggested as to why not the household saved as: lack of sufficient income, transfer to other duties and there is saving. Having the information from the respondents the probability to be poor increase as the households head become non saver due to lack of sufficient income. While non-savers due to transfer to other duties are less vulnerable to poverty

- Possession of physical capital: It is obvious that, wellbeing resides in living and getting life sustaining goods and services. One of these elements is access to pure water which is basic for the health and smooth functioning of one's body. But in many cases, the poor have no access to such service. Access to pure water is mostly related to the source. In most cases residents of cities get water service from water supply agencies. But in terms of the coverage of the service the poor are not reached by these services. The main reason is that, the poor can't afford to pay for the initial installation of the equipment's.

\section{CONCLUSSION}

If we have to conclude my review: Poverty is a threat to the world, especially developing countries. The governments, national and international development institutions have tried to understand the nature of poverty and mechanisms of reducing it. Poverty alleviation is a key policy debate in recent development literature. Many researchers of development economics have argued that the fight against poverty is a necessary condition for sustainable Economic growth. The majority of the populations in developing countries live in rural areas. As a result, it is widely accepted that a well-studied and organized interventions in these areas play a key role in socio-economic transformations of poor countries. In the view of that, this review aimed to show current poverty status, and to review the causes and determinants of poverty in Ethiopia and their policy implications. As we review the Results of research conducted by different scholars on poverty in Ethiopia the probability of being in poverty is determined by lack work experience, lack/low livestock possession, lack of access to market information and distance from local market.

In general, the Government of Ethiopia's focus on agricultural growth and investments in basic services for all has ensured improvements in wellbeing for many poor households in Ethiopia. The proportion of the population living below the national poverty line fell from $44 \%$ in 2000 to $30 \%$ in 2011 . Looking forward, further investment in basic services are required to ensure that Ethiopia continues to make further, needed, progress in education, health, and living standards. Investments in safety nets remain important to reduce vulnerability. The predominance of agriculture as a source of income for Ethiopia's poor also suggests that agricultural growth will remain an important driver of poverty reduction in the future. Poverty reduction from agricultural productivity increases has occurred in places with better market access when cereals prices have been high, underscoring the dependence of agricultural growth on increased urban demand for agricultural products in a land-locked country such as Ethiopia.

However, the structural change in value addition that has occurred during the last decade has not been fully matched by structural change in employment. The analytical findings presented here are consistent with the idea that further agglomeration through urbanization would help increase poverty reduction. This will require policies that favor the entry and growth of firms, in addition to support to self-employment in non-agricultural activities. Further urbanization and growth in non-agricultural sectors would continue to exert upward pressure on food prices. This will needto be met by agricultural productivity growth in order to keep labor costs competitive, but high prices incentivize the required agricultural investments. Although beneficial for many poor rural households, high food prices carry costs for the urban poor. Improving the fiscal position of poor urban households - such as through higher direct transfers or raising the minimum income above which personal income tax is levied- 
would help offset this effect.

The expansion of financial institutions, awareness creation, incentives should guide financial institutions' activity in order to increase the number of savers and amount of saving. The current remarkable effort of electrification should be further intensified and reliable in its supply since poverty reduces more due to use of it for both cooking and lighting.

The very urban poor have to be identified rigorously and supported by pro-poor projects and programs such as urban safety nets, subsidized food items...etc. Moreover, since education is commonly recommended as a plausible option to reduce inequality, the direct and indirect costs of it should be systematically reduced for the very poor via supporting education materials, financing cost of uniforms, providing assets to the family, school feeding...etc. Doing so will increase participation and reduce drop out from the school among the very poor.

\section{REFERENCES}

Addisu M. B. and Rao M. S. (2014).Modeling the Determinants of Rural Household Poverty: Evidence from Ethiopia.ZENITH International Journal of Business Economics \& Management Research Vol.4 (12), pp. 165-177 ISSN 2249- 8826 ZIJBEMR.Online available at zenithresearch.org.in.

Adepoju A.O. (2012). Poverty Transitions in Rural South West Nigeria. Global Journal of Science Frontier Research: Agriculture \& Biology Volume 12 Issue 2 Version 1.0 January 2012, Online ISSN: 2249-4626 \& Print ISSN: 0975-5896.

Ahmed M. A. (2013). Determinants of Poverty in Rural Ethiopia: A Household Level Analysis. A master thesis submitted to Lund University, School of Economics and management.

Alemayehu, G., De Jong, N., Kimenyi, M.S. and Mwabu, G.(2005). Determinants of Poverty in Kenya: A Household Level Analysis. Economics Working Papers.

Ayalneh B., Hagedorn K. and Korf B (2005).Determinants of poverty in rural Ethiopia.Quarterly Journal of International Agriculture 44 (2005), No. 2: 101-120.

Ayalneh B. (2011). Analysis of poverty and its covariates among smallholder farmers in theEasternHararghe highlands of Ethiopia. Journal of Development and Agricultural Economics Vol. 3(4), pp. 157-164, Available online at http://www.academicjournals.org/JDAE.ISSN 2006- 9774 C2011 Academic Journals.

Alkire, S. and J. Foster (2011).Counting and multidimensional poverty measurement. Journal of public economics, 95(7-8):476-487.

Andersson, M., Engvall, A., Kokko, A(2005). Determinants of Poverty in Lao PDR.

Apata, T. G., Apata, O. M., Igbalajobi, O. A. and Awoniyi, S. M. O.(2010). Determinants of rural poverty in Nigeria: Evidence from small holder farmers in South-western, Nigeria.

Academic Journals. Journal of Science and Technology Education Research Vol. 1(4), pp. 85 91. Available online http://www.academicjournals.org/JSTER.

Asmamaw, E. (2004). Understanding Poverty: The Ethiopian Context; Paper presented at The Gambia AAPAM Roundtable Conference, Banjul, the Gambia, April 19 - 23, 2004.

Bahta, Y.T., and Haile, B.O.(2013). Determinants of Poverty of ZobaMaekel of Eritrea: A Household Level Analysis. International Journal of Food and Agricultural Economics Vol. 1 No. 2 Pp 73-84 73.ISSN 21478988.

Bigsten, A. and Shimeles, A.(2008). Poverty Transition and Persistence in Ethiopia:1994-2004.World Development Vol. 36, No. 9, pp. 1559-1584

Bogale, A.(2011). Analysis of poverty and its covariates among smallholder farmers in theEastern Hararghe highlands of Ethiopia. Journal of Development and Agricultural Economics Vol. 3(4), pp. 157-164. Available online at http://www. academicjournals.org/JDAE.

Bourguignon, F. and S.R. Chakravarty (2003).The measurement of multidimensional poverty.Journal of Economic Inequality, 1, 25-49.

Boccanfuso, D. (2004). A Conceptual Framework for Approaches to Poverty, OverviewPaper, IDRC.

Bradshaw, T.K.(2006). Theories of Poverty and Anti- Poverty Programs in Community Development.RPRC(Rural Poverty Research Center) Working Paper No. 06-05.

Chen, K. M., \& Wang, T. M. (2015). Determinants of Poverty Status in Taiwan: A Multilevel Approach. Social Indicators Research, 123(2), 371-389.

D'Ambrosio, C., Deutsch, J., \& Silber, J. (2011). Multidimensional Approaches to Poverty Measurement: an Empirical Analysis of Poverty in Belgium, France, Germany, Italy and Spain, Based on the European Panel. Applied Economics, 43(8), 951-961.

Dartanto, T., \&Nurkholis. (2013).The Determinants of Poverty Dynamics in Indonesia: Evidence from Panel Data. Bulletin of Indonesian Economic Studies, 49(1), 61-84.

Dercon. S, and M. Tadesse.1999“A Comparison of Poverty in Rural and Urban Ethiopia.”,Ethiopian Journal of Economics 8, no. 1: 83-98.

Dercon, S. (2001), "Income Risk, Coping Strategies and Safety Nets," Centre for theStudy of African Economies, 
Department of Economics, Oxford University

Eriksen, S.H. (2000). Responding to global change: Vulnerability and management of local agro-ecosystems in Kenya and Tanzania.PhD thesis, University of East Anglia, Norwich, UK.

Frerer, K. and Vu, C. (2006).An Anthropological View of Poverty.In B.B. Austin, M.J. (2006).Understanding Poverty from Multiple Social Science Perspectives.

Hashmi, A.A., Sial, M.H. and Hashmi, M.H.(2008).Trends and Determinants of RuralPoverty: A Logistic Regression Analysis of Selected Districts of Punjab. The Pakistan Development Review, vol. 47, issue 4, pages 909-923.

Hulme, D. and A. Shepherd (2003).Conceptualizing chronic poverty. World Development 31(3), 403-423.

Ibrahim, H. and Umar, H.S. (2007). Determinants of Poverty among Farming Households inNasarawaState,Nigeria. PAT Volume 4 Issue 1, page 11-21: ISSN: 0794-5213. Online copyavailable at www.patnsukjournal.com/currentissue.

Ibrahim, H. and Umar, H.S.(2008). Determinants of Poverty among farming Households in Nasarawa State, Nigeria. Media and Agricultural Marketing.PAT 2008; 4 (1): 11-21: ISSN: 0794-5213. Online copy available at www.patnsukjournal.com/currentissue.

Kedir, A (2003). Chronic poverty in Urban Ethiopia, "Staying poor: Chronic poverty and Development policy." Manchester, UK,

Kanbur, R. (2002).Conceptual Challenges in Poverty and Inequality: One Development Economist's Perspective. Department of Applied Economics and Management; Cornell University.

Khudri, M. M., \&Chowdhury, F. (2013).Evaluation of Socio-economic Status of Households and Identifying Key Determinants of Poverty in Bangladesh. European Journal of Social Sciences, 37(3), 377-387.

Lehning, A.J.(2006). Political Science Perspectives on Poverty.In B.B. Austin, M.J.(2006). Understanding Poverty from Multiple Social Science Perspectives

Malik, S. Chaudhry, I.S. and Hanif, I.(2012). Analysis of Rural Poverty in Pakistan; Bi-ModelEstimation of Some Selected Villages.InternationalJournal of Humanities and Social Science Vol. 2 No.

Maru S. B. (2004). Rural Poverty and Its Determinants in Zeghe Peninsula, Bahir Dar ZuriaWoreda. Master's thesis submitted to Addis Ababa University, School of Graduate Studies.

Metalign A. T. (2005). Rural Poverty Situation and Determinants: The case of KersaKondaltityWoreda, South West Shewa. Master's thesis submitted to Addis Ababa University, School of Graduate Studies.

MOFED (Ministry of Finance and Economic Development) (2002): Ethiopia: SustainableDevelopment and Poverty Reduction. Draft. Addis Ababa.

MoFED, Ministry of Finance and Economic Development (2012)'Ethiopia's progress towarderadicating poverty: an interim report on poverty analysis study (2011/2012)', Developmentplanning and research directorate, Ministry of Finance and Economic Development, FederalDemocratic Republic of Ethiopia.March 2012, Addis

Ababa. Accessedonline:http://www.mofed.gov.et/English/Resources/Documents/Interim\%20Report\%20on\%20201 0-11\%20Poverty\%20Analysis.pdf.Accessed on August 12, 2012.

Muhdin M. (2015). Determinants of Rural Income Poverty in Ethiopia: Case Study of Villagesin Dodola District. Global Journal of Management and Business Research: (B) Economics andCommerce, Volume 15 Issue 11 version 1.0. Online ISSN: 2249-4588 \& Print ISSN: 0975-5853.

Namara, R., Makombe, G., Hagos, F., Awulachew, S.B. (2010). Rural poverty and inequality in Ethiopia: does access to small-scale irrigation make a difference?

Nguyen, H. T.; W. N. Adger.and P.M. Kelly (1998). Natural resource management in mitigating climate impacts:

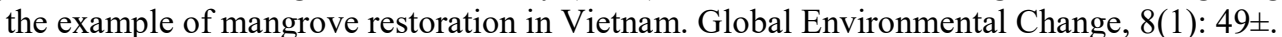

Ravallion.M (1994), Poverty and policy.Handbook of Development Economics, Vol IIIB, Washington, DC, World Bank.

Ravallion, M. (1998).Living Standards Measurement Study.The World Bank-Washington, DC.

Rowntree, S. (1901) Poverty. The Study of Town Life. London: Macmillan.http://www.jrf.org.uk/centenary/poverty.html

Rupasingha, A., \& Goetz, S. J. (2007). Social and Political Forces as Determinants of Poverty: A Spatial Analysis. The Journal of Socio-Economics, 36(4), 650-671.

Sabir. H.M., Hussain, Z. and Saboor, A.(2006). Determinants of Small FarmersPoverty In The Central Punjab (Pakistan). Journal of Agriculture \& Social Sciences.1813 2235/2006/02-1-10-12.

Sekhampu, T.J.(2013). Determinants of Poverty in aSouth African Township.Kamla Raj 2013 J SocSci,34(2): $145-153$

Sen, A. (1976). Poverty: an ordinal approach to measurement. Econometrica, 44, 219-231.

Sen, A. (1981). Poverty and famines: An essay on entitlement and deprivation. Oxford University Press.

Sen, A. (1985). Commodities and capabilities. Amsterdam: North-Holland.

Sen, A. (1996). On the foundations of welfare economics: Utility, capability and practical reason. 
Selim, S. (2016). Socio-Economic Determinants of Poverty in Turkey: Panel Logit Approach. International Journal of Statistics \& Economics ${ }^{\mathrm{TM}}, 17(3), 71-84$.

Swanepoel, C.(2005). Poverty and Poverty Dynamics in Rural Ethiopia. Stellenbosch Economic Working Papers : 3 / 2005

Tadesse, M.1999. "Determinants and Dynamics of Urban Poverty in Ethiopia.” Ethiopian Journal of Economics 8 , no. $1: 61-82$.

Tesfahun.M.A. (2005). Rural Poverty Situation and Determinants: The Case of KersaKondaltityWoreda, South West Shewa. Thesis submitted to the School of Graduate Studies, Addis Ababa University.

Tilman, B. and Sindu, W.K.( 2013). Dynamics and Drivers of Consumption and Multidimensional Poverty: Evidence from Rural Ethiopia. IZA Discussion Paper, No. 7364.

Townsend, P. (1970). The Concept of Poverty. London: Heinemann

Tsegaye M. (2014). Household Level Analysis of Rural Poverty: The Case of Gozamn Districtof East Gojjam Zone, Ethiopia. M.Sc. thesis submitted to Haramaya University, Ethiopia.

UNDP.(1990). Human Development Report. New York: Oxford University Press.

UNDP, 2003 Human Development Report 2003. New York, Oxford University Press.

World Bank .2000, World Development Report: Attacking Poverty. New York, Oxford University Press.

Wolf, J.P.( 2006). Sociological Theories of Poverty in Urban America.

World Bank Institute (2005). Introduction to Poverty Analysis: Poverty Manual. 